\title{
Pengaruh Biaya Operasional dan Pendapatan Operasional, Net Operating Margin, Dana Pihak Ketiga dan Capital Adequacy Ratio terhadap Profitabilitas Bank Syariah (The Effect of Operational Efficiency Ratio, Net Operating Margin, Third Party Funds and Capital Adequacy Ratio on Profitability with Financing to Deposito Ratio as Intervening Variable in Islamic Commercial Bank)
}

Rahma Aulia ${ }^{1}$, Saiful Anwar ${ }^{2 *}$

Fakultas Ekonomi dan Bisnis Islam, Institut Agama Islam Negeri Salatiga, Salatiga, Jawa Tengah ${ }^{1,2}$ rahmaaul2199@ gmail.com $^{l}$, saifulanwarmieta@iainsalatiga.ac.id ${ }^{2 *}$

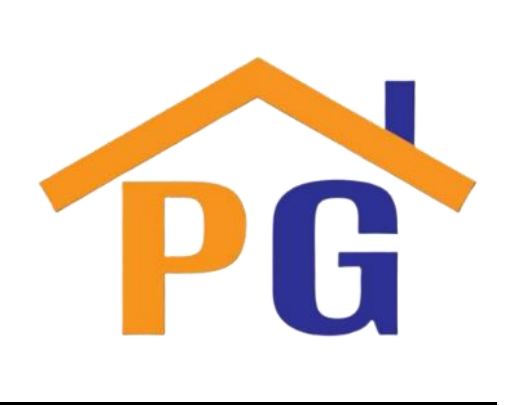

Riwayat Artikel

Diterima pada 29 Juni 2021

Direvisi pada 16 Juli 2021

Disetujui pada 16 Juli 2021

\begin{abstract}
Purpose: This study examined the effect of Operational Efficiency Ratio (BOPO), Net Operating Margin (NOM), Third Party Funds (DPK) and Capital Adequacy Ratio (CAR) On Profitability With Financing To Deposito Ratio (FDR) As Intervening Variable in Islamic Commercial Bank.
\end{abstract}

Research Methodology: The sample used in this study was 11 banks with the sampling technique using purposive sampling. The analytical method used was multiple linear regression

Results: The results show that the variables BOPO and NOM have no effect on FDR. DPK and CAR have a positive and significant effect on FDR. FDR and NOM have a positive and significant effect on Profitability. BOPO, DPK and CAR have no effect on Profitability. FDR is able to be an intervening variable in the relationship between DPK and CAR to Profitability. FDR is not able to be an intervening variable in the relationship between BOPO and NOM to Profitability.

Limitations: The sample of this study was only 11 Islamic commercial banks and only used the Islamic banking sector in Indonesia, which is listed on the Indonesia stock exchange.

Contribution: The research is helpful for further investigation. One of the guidelines in choosing which variables to use and which one to use in the study should be understood in selecting Islamic financial performance.

Keywords: $B O P O, N O M, D P K, C A R$, Profitability, FDR

How to cite: Aulia, R., \& Anwar, S. (2021). Pengaruh Biaya Operasional dan Pendapatan Operasional, Net Operating Margin, Dana Pihak Ketiga dan Capital Adequacy Ratio terhadap Profitabilitas Bank Syariah. Bukhori: Jurnal Ekonomi dan Keuangan Islam, 1(1), 21-38.

\section{Pendahuluan}

Sistem perbankan merupakan bentuk implementasi yang mendukung intermediasi keuangan suatu negara. Produk-produk tersebut diarahkan untuk kegiatan ekonomi nasional sehingga belum terintegrasi secara tinggi ke dalam sistem keuangan global. Inilah salah satu alasan mengapa bank syariah bisa bertahan. Dengan berdirinya Islamic Development Bank (IDB) di Jeddah pada tahun 1975, perkembangan Islam terus berlanjut, yang kemudian mendorong berdirinya bank-bank syariah 
di seluruh dunia, termasuk kawasan Eropa. Kantor Pelayanan/OJK menyebutkan bahwa pada tahun 2015 terdapat 12 Bank Umum Syariah (BUS) dan 22 Unit Usaha Syariah (UUS). Pada tahun 2016, berkembang menjadi 13 bank umum syariah dan 21 unit usaha syariah (Prasaja, 2020).

Setiap bank termasuk bank konvensional dan syariah, wajib menyerahkan dan mempublikasikan laporan tahunan yang salah satunya terbuka untuk umum untuk melihat kinerja bank tersebut. Hal ini penting karena kepercayaan masyarakat terhadap terjaganya dana bank sangat bergantung pada kinerja bank. Memeriksa status laporan posisi keuangan dan laporan laba rugi sangat penting dalam melihat kinerja bank syariah. Perbandingan saldo bank dari bank lain atau waktu atau tahun yang berbeda. Atas dasar laporan keuangan tahunan tersebut dapat dihitung berbagai rasio keuangan yang biasanya digunakan sebagai dasar penilaian kinerja bank. Indikator keuangan dapat digunakan untuk mengukur kinerja karena indikator tersebut telah terbukti berperan penting dalam menilai kinerja keuangan dan dapat digunakan untuk memprediksi kelangsungan usaha, apakah sehat atau tidak sehat. Mengevaluasi efektivitas bisnis perbankan. Hal ini dilakukan dengan menganalisis rasio keuangan (Siregar, 2020).

Profitabilitas merupakan rasio yang menjelaskan tentang bagaimana kinerja suatu perbankan berdasarkan susunan kegunaan serta keefektifan operasi perbankan dalam mendapatkan keuntungan. Profitabilitas diperlihatkan dari keuntungan yang didapat melalui pemanfaatan aset bank syariah. Jadi bisa juga diartikan merupakan keahlian perbankan untuk memperoleh profit. Setiap perbankan harus memiliki rasio profitabilitas yang besar. Hal tersebut disebabkan karena profitabilitas yang besar menunjukkan perbankan telah menjalankan usahanya dengan baik. Apabila sebuah perbankan tidak memiliki keuntungan, maka perbankan sangat sulit untuk melangsungkan operasinya (mengalami collapse).

Berikut ini merupakan perkembangan industri perbankan dari tahun 2019. Dilansir dari www.cnbcindonesia.com pada 11 Februari 2021 Heru Kristiyana selaku Kepala Eksekutif Pengawas OJK, mengatakan bahwa industri perbankan Syariah mengalamani tekanan rasio profitabilitas yang berimbas pada implementasi restrukturisasi kredit. Maksudnya, rasio profitabilitas mengalami penurunan dan ini berimbas pada upaya perbaikan dalam kegiatan perkreditan. Hal ini dilihat berdasarkan penurunan rasio NOM yang awalnya 2,01\% per Desember 2019 menjadi 1,55\% per Desember 2020. Di sisi lain, rasio BOPO mengalami kenaikan dari 82,52\% per Desember 2019 menjadi 83,63\% per Desember 2020.

Tujuan utama yang diharapkan saat mengelola suatu usaha khususnya pihak bank ialah mendapatkan daya keuntungan. Hal tersebut disebabkan karena saat menjalankan operasional usahanya, bank berusaha untuk mendapatkan profit yang tertinggi. Oleh karena itu pihak perbankan selalu berusaha memaksimalkan kinerja keuangannya (Yusup \& Norita, 2009).

Bank Indonesia menemukan bahwa Return On Assets (ROA) merupakan salah satu indikator profitabilitas perbankan. ROA digunakan untuk mengukur efisiensi dan efektivitas keuntungan perusahaan dari penggunaan asetnya. ROA sangat penting bagi bank karena ROA digunakan untuk mengukur efektivitas penggunaan aset perusahaan untuk menghasilkan keuntungan. Perusahaan dengan profitabilitas yang baik menunjukkan bahwa perusahaan tersebut memiliki prospek yang baik, dan perusahaan tersebut menjadi kelangsungan yang dapat dipertahankan perusahaan (Almunawwaroh \& Marliana, 2018). ROA ialah tingkat yang memperlihatkan keahlian dari semua asset yang akan dipakai untuk memperoleh profit. Semakin besar tingkat rasio ROA dalam suatu bank, maka tingkat profit yang diperoleh bank juga tinggi. Lukman (2018) rasio ROA yang besar akan menjadikan posisi bank semakin baik dari segi penggunaan asset. Berikut ini disajikan tabel rasio ROA bank umum syariah dari tahun 2015-2019. 
Tabel 1. Rasio Return On Asset

\begin{tabular}{cccccc}
\hline \multirow{2}{*}{ Rasio } & \multicolumn{5}{c}{ Tahun } \\
\cline { 2 - 5 } & 2015 & 2016 & 2017 & 2018 & 2019 \\
\hline ROA & $2,20 \%$ & $2,27 \%$ & $2,55 \%$ & $1,87 \%$ & $2,61 \%$ \\
\hline \multicolumn{6}{l}{ Sumber: Statistik Perbankan Syariah 2020 }
\end{tabular}

Tabel di atas mengambarkan keadaan bank Syariah melalui rasio profitabilitas. Tahun 2015 profitablitas bank Syariah mencapai kenaikkan hingga 2,20\%. Di tahun selanjutnya mencapai 2,27\%. Terjadi fluktuasi dari 2017-2016, dikarenakan dari 2,55\% kemudian turun ke 1,87\% dan kembali naik $2,61 \%$. Kenaikan maupun penurunan rasio ROA yang telah terjadi seperti apa yang disajikan dalam tabel 1.1, menunjukkan jika profitabilitas bank syariah sangat tergantung pada faktir-faktor tertentu Indikator yang menentukan profitabilitas perbankan syariah biasanya ditentukan oleh faktor internal dan eksternal perusahaan. Faktor internal industri perbankan tercermin dalam operasional bisnisnya untuk menghasilkan produk dan layanan yang efisien.

M. Yusuf (2017) BOPO (Biaya Operasional/Pendapatan Operasional) ialah tingkat yang dipakai guna membedakan biaya kegiatan bank dengan penghasilan yang berhasil dibukukan. Melalui perhitungan rasio ini, bank dapat mengetahui tingkat efisiensi direksi/manajemen dalam mengelola kegiatan operasional cabang/unit kerja. Angka BOPO yang rendah menandakan efisiensi (ketepatan kerja) sebuah bank cukup baik guna mengendalikan biaya opeasional. Dengan tingkat efisiensi yang baik maka kemungkinan bank memperoleh keuntungan yang tinggi juga akan semakin besar. Sementara, NOM adalah parameter yang akan dihitung dalam riset aspek daya laba.

NOM ialah tingkat yang mendeskripsikan penghasilan kegiatan bersih, jadi dari hal tersebut dapat dilihat keahlian rata-rata aktiva produktif dalam memperoleh keuntungan (Rivai et al., 2007). Net Interest Margin ini dipergunakan sebagai dasar untuk dilakukannya penilaian bank dalam mengatasi kemungkinan bahaya yang terjadi pada keuntungan serta pembagian dari hasil. Hal ini menandakan, ketika keuntungan/pembagian hasil berbeda, maka penghasilan dan biaya laba/pembagian dari hasil juga akan berbeda. Hal ini disebabkan NOM sendiri ialah tingkatan yang berhubungan erat dengan keahlian sebuah bank dalam melakukan pengelolaan. Manajemen ini dibutuhkan untuk mengerjakan aktiva produktif, yang kemudian akan memperoleh keuntungan/pembagian dari hasil yang bersih.

Yundi \& Sudarsono (2018) menjelaskan jika uang yang dipunyai oleh sebuah bank, memiliki peranan utama untuk merencanakan investasi serta saat mengerjakan operasional usaha bank lainnya. Masyarakat mempercayakan dana mereka kepada bank berupa giro, deposito, tabungan, dan lainnya. Tentunya, masyarakat mempercayakan dana tersebut kepada pihak bank merujuk pada perjanjian penahanan uang dalam bentuk tertentu didasarkan pada persetujuan bersama. Jika Dana Pihak Ketiga (DPK) semakin besar dalam sebuah bank, maka kemampuan pengelolaan bank syariah untuk memindahkan uangnya berupa pembelanjaan juga akan besar.

Tokoh Soliha \& Taswan (2002) mengatakan jika likuiditas merupakan keahlian sebuah bank dalam menyediakan uang yang cukup. Saat ini, pengelolaan likuiditas adalah permasalahan yang dianggap cukup rumit untuk diatasi dalam kegiatan operasional bank. Kesulitan dalam mengelola likuiditas ini diantaranya dapat disebabkan oleh sebagian besar uang yang didapat dari masyarakat bersifat jangka pendek, serta bisa diambil kapanpun. Perkembangan bank Syariah di Indonesia ini juga bisa diperlihatkan dari FDR yang semakin tinggi di setiap tahunnya. FDR adalah tingkatan yang dapat dipakai untuk menakar suatu likuiditas dari sebuah bank untuk bisa mengangsur lagi, yang di diadakan oleh pihak nasabah dengan mengunakan pembiayaan yang sudah dikasihkan sebagai sumber likuiditasnya (Almunawwaroh \& Marliana, 2018).

Oleh karena itu yang melatar belakangi riset ini ialah research gap, dimana ditemukannya hasil riset sebelumnya yang mempunyai hasil yang tidak sama. Hasil riset dengan isu BOPO terhadap FDR yang dilakukan Jannah \& Gunarso (2020) dan Kartini \& Nuranisa (2016) ini berpengaruh positif signifikan. $\underline{\text { Ichwan (2017) }} \underline{\text { Hasbidin (2017) }}$ dan Sengkey et al. (2018) berpengaruh negatif signifikan. Hasil riset 
dari Ariyanti et al., (2017) hasilnya nya berbeda tidak memberikan pengaruh. Sedangkan riset NOM terhadap FDR menurut Purbasari (2018) dan Musa et al., (2019) mengatakan bahwa hasilnya positif. Mayasari (2019) yang hasilnya negatif signifikan. Sedangkan dari Cholida \& Sri (2016) dan Ariyanti et al. (2017) mengatakan hal yang berbeda bahwa tidak berpengaruh.

Penelitian empiris mengenai pengaruh DPK terhadap profitabiltas telah dilakukan oleh Prihatiningsih (2012) yang menghasilkan temuan DPK berpengaruh negatif tidak signifikan terhadap profitabilitas. Temuan M \& Muslikhati (2019) dan Fikriati (2015) memiliki hasil negatif signifikan yang berbanding terbalik dengan penelitian sebelumnya. Sedangkan temuan Enny (2016) menunjukkan pengaruh positif. Hasil penelitian CAR terhadap FDR yang dilakukan Prihatiningsih, (2012) dan Purbasari, (2018) memiliki hasil negatif signifikan. Agustini \& Wardana (2018) dan Ardiansari et al. (2016) hasilnya positif signifikan. Sedangkan Santoso \& Sukihanjani (2016) dan M \& Muslikhati (2019) memiliki hasil yang berbeda tidak berpengaruh signifikan.

Hasil riset dari FDR terhadap profitabilitas menurut Yusuf (2017), Almunawwaroh \& Marliana (2018) dan Ubaidillah (2016) memiliki hasil positif signifikan. Sedangkan temuan A'la \& Imron (2015) memiliki hasil signifikan. Disisi lain menurut Pratiwi \& W (2016) hasilnya positif tidak signifikan. Damayanti \& S, (2012) memiliki hasil yang berbeda tidak berpengaruh. Isu dari BOPO terhadap profitabilitas dari riset Peling \& Sedana (2018), Saputra \& Budiasih (2016), Pinasti \& Mustikawati (2018) W. M. Yusuf \& Wahyuni (2017) Ariyanti et al. (2017) hasilnya negatif signifikan. Dan riset dari (Achmad, 2018), Reviyana \& Lestari (2016), Setiawan, (2015) memiliki hasil riset positif signifikan, akan tetapi hasil dari (Sintiya, 2018) hasilnya berbeda tidak berpengaruh.

Isu NOM terhadap profitabilitas hasil riset dari M. Yusuf (2017) positif. W. M. Yusuf \& Wahyuni $\underline{\text { (2017) }}$ hasilnya positif signifikan. Dan hasil berbeda dari riset Ariyanti et al. (2017) dan $\underline{\operatorname{Harun}(2016)}$ tidak berpengaruh. Isu DPK terhadap profitabilitas riset dari Jyana \& Affandi (2019) Parenrengi et.al (2018) Yundi \& Sudarsono (2018) U. N. A. Setiawan \& Astiwi (2016) yang hasilnya berpengaruh positif signifikan. Riset dari Sukma et al. (2019) hasilnya positif tidak berpengaruh signifikan. Akan tetapi riset yang berbeda dihasilkan dari (Husaeni, 2017) dan Wahyuda et al. (2017) yang hasilnya negatif tidak signifikan.

Isu dari CAR terhadap profitabilitas riset dari Suwarno \& Muthohar (2018) hasilnya positif tidak signifikan. Berbanding terbalik dengan temuan W. M. Yusuf \& Wahyuni (2017) dan Maulana et al. $\underline{(2019)}$ yang menegaskan hasil positif signifikan. Sedangkan temuan Muliawati \& Khoiruddin (2015) dan Almunawwaroh \& Marliana (2018) hasilnya negatif. Akan tetapi riset dari Ichwan (2017) yang hasilnya berbeda tidak berpengaruh.

Maka dari itu FDR yang merupakan variabel mediasi dari pengaruh BOPO NOM DPK dan CAR terhadap profitabilitas bank syariah. Hal tersebut disebabkan FDR berfungsi sebagai tingkatan dari kinerja bank yang dapat menakar tingkatan dari likuiditas yang dipunyai oleh suatu bank. Sehingga didukung dari riset Pardede \& Pangestuti (2016) Lidyah et al., (2019) yang mengatakan bahwa FDR mampu memediasi. Dan riset dari (Fitria \& Widiati, 2018) hasilnya tidak terdapat pengaruh mediasi.

\section{Tinjauan pustaka dan pengembangan hipotesis}

\subsection{BOPO, NOM, DPK, CAR terhadap FDR terhadap Profitabilitas}

Biaya Operasional terhadap penghasilan Operasional mempunyai pengaruh pada keahlian bank dalam menjalankan operasionalnya terhadap penghasilan dari operasionalnya (Lukman, 2009). Jadi semakin kecil rasio BOPO maka semakin efisien biaya operasional yang dibayarkan oleh pihak bank berkaitan. Hal tersebut didukung oleh riset Ichwan (2017) Hasbidin (2017) dan Sengkey et al. (2018) yang menjelaskab bahwa arti BOPO memiliki dominasi negatif signifikan terhadap FDR. Untuk itu H1: BOPO berpengaruh negatif signifikan terhadap FDR pada Perbankan Syariah Tahun 2015-2019.

NOM adalah indeks yang mengukur kemampuan manajemen bank untuk mengelola fasilitas untuk menghasilkan pendapatan operasional bersih. Semakin tinggi jumlahnya, semakin tinggi pula proporsi pendapatan dari aset produktif, sehingga kemungkinan bank bermasalah semakin kecil. Dapat 
disimpulkan bahwa semakin banyak perubahan NOM suatu bank maka semakin tinggi profitabilitas bank tersebut, yang berarti indikator keuangan akan meningkat. Hal tersebut didukung riset dari Purbasari, R. N. (2018). Pengaruh KAP, CAR, SIZE, Dan NOM Terhadap Financing To Deposit Ratio (FDR) Pada Bank Umum Syariah Di Indonesia Periode 2012-2016. In Jakarta: Fakultas Ekonomi dan Bisnis UIN Syarif Hidayatullah Jakarta (Vol. 2).Purbasari (2018) dan Musa et al. (2019) yang berarti NOM mempunyai pengaruh yang positif terhadap FDR. Hal tersebut mendorong $\mathrm{H} 2$ : NOM berpengaruh positif terhadap FDR pada Perbankan Syariah Tahun 2015-2019.

Prihatiningsih (2012) dalam risetnya menyebut jika nilai DPK yang tinggi tidak berarti nilai FDR juga akan meningkat. Hal ini dikarenakan bank Syariah rata-rata mempunyai tingkat FDR yang tinggi guna menjaga likuiditas serta mengantisipasi DPK yang ditarik kapan saja oleh nasabah. Hal tersebut didukung riset dari Prihatiningsih (2012) Utami \& Muslikhati (2019) dan Fikriati (2015) yang berarti DPK mempunyai pengaruh negatif terhadap signifikan. Untuk itu H3: DPK berpengaruh negatif signifikan terhadap FDR pada Perbankan Syariah Tahun 2015-2019.

CAR ialah tingkatan yang dipakai guna mengetahui keahlian bank dalam menanggulangi bahaya yang kemungkinan bisa terjadi akibat dari aktivitas bisnis dengan modal yang dimiliki. Semakin tinggi kredit yang berhasil tersalurkan maka akibat yang harus dilakukan oleh bank juga akan semakin tinggi sehingga mempengaruhi nilai CAR yakni nilai CAR akan semakin kecil. Hal tersebut didukung riset dari Agustini \& Wardana (2018) Ardiansari et al. (2016) dan Ariyanti et al. (2017) yang menerangkan bahwa CAR memiliki keterkaitan positif signifikan terhadap FDR. Untuk itu, H4: CAR berpengaruh positif terhadap FDR pada Perbankan Syariah Tahun 2015-2019.

Penyaluran kredit merupakan sumber utama penghasilan bank Syariah. Berbagai jenis akad kredit yang ditawarkan kepada nasabah baik dalam bentuk jual beli, Kerjasama maupun bentuk lainnya mempunyai pengaruh bagi kemampuan entitas dalam menghasilkan profit (A'la \& Imron, 2015) Hal tersebut didukung riset yang dikerjakan M. Yusuf (2017) Almunawwaroh \& Marliana (2018) Pratiwi \& Wiagustini (2015) Ubaidillah (2016) yang menerangkan bahwa FDR mempunyai pengaruh positif serta signifikan terhadap profitabilitas yang artinya semakin tinggi FDR akan memberikan pengaruh pada kenaikan daya keuntungan. Narasi ini memunculkan H5: FDR berpengaruh positif signifikan terhadap profitabilitas pada Perbankan Syariah Tahun 2015-2019.

\subsection{BOPO, NOM, DPK, dan CAR terhadap Profitabilitas}

Hasbidin (2017) BOPO yang rendah memperlihatkan semakin tinggi efisiensi kegiatan yang diperoleh oleh bank dalam melaksanakan kegiatan usahanya. Jika BOPO semakin naik dalam arti biaya kegiatan bank semakin besar, jadi akan mengakibatkan keuntungan semakin turun. Sehingga akhirnya akan mengakibatkan profitabilitas bank ikut turun. Hal tersebut didukung riset yang dikerjakan Peling \& Sedana (2018), Saputra \& Budiasih (2016), Pinasti \& Mustikawati (2018), W. M. Yusuf \& Wahyuni (2017), dan Ariyanti et al., (2017) yang menjelaskan bahwa BOPO mempunyai pengaruh negatif signifikan terhadap ROA. Untuk itu, H6: BOPO berpengaruh negatif signifikan terhadap profitabilitas pada Perbankan Syariah Tahun 2015-2019.

NOM ialah tingkatan yang memperlihatkan keahlian manajemen bank dalam menjalankan aktiva produktifnya untuk mendapatkan penghasilan yang bersih. Semakin besar NOM maka penghasilan bagi hasil atas aktiva produktif juga meningkat, hal tersebut memungkinkan jika keadaan bank mengalami masalah juga semakin kecil.

Bisa dijelaskan bahwa semakin besar NOM suatu bank, maka semakin besar pula daya laba bank semakin tinggi performance keuangannya (Yusup \& Norita, 2009). Besar kecilnya NOM suatu bank akan memberikan pengaruh pada kinerja bank itu. Hal tersebut didukung riset dari M. Yusuf (2017) dan W. M. Yusuf \& Wahyuni (2017) yang berarti berpengaruh positif signifikan. Hal tersbutu mendorong H7: NOM berpengaruh positif signifikan terhadap profitabilitas pada Perbankan Syariah Tahun 2015-2019. 
Lukman (2009), uang dari masyarakat adalah sumber keuangan paling besar yang bisa dijagokan oleh bank yang memperoleh $80 \%-90 \%$ dari keseluruhan harta yang dijalankan oleh pihak bank. Sumber dana pihak ketiga adalah hal paling penting bagi operasiona suatu bank serta menjadi takaran kesuksesan bank. Apabila bank membiayai kegiatannya dari sumber uang ini, (Kasmir, 2014). Hal tersebut didukung riset dari Jyana \& Affandi (2019), Parenrengi \& Tyahya Whisnu H (2018), Yundi \& Sudarsono (2018) dan Setiawan \& Astiwi (2016) menjelaskan jika DPK mempunyai pengaruh positif terhadap rasio daya keuntungan. Untuk itu, H8: DPK berpengaruh positif signifikan terhadap profitabilitas pada Perbankan Syariah Tahun 2015-2019.

Hakiim (2018) menyebut bila nilai CAR mampu mempengaruhi kemampuan entitas dalam memperoleh laba bersih. Merujuk pada ketentuan dari BI nilai CAR maksimum yang harus dipunyai oleh bank yakni 8\%. Hal tersebut didukung riset dari W. M. Yusuf \& Wahyuni (2017) dan Maulana et al. (2019) yang menjelaskan jika CAR punya dominasi positif serta signifikan terhadap profitabilitas. Sehingga H9: CAR berpengaruh positif signifikan terhadap profitabilitas pada Perbankan Syariah Tahun 2015-2019.

\subsection{FDR memediasi BOPO, NOM, DPK, dan CAR}

Almila \& W (2005) dalam menyatakan apabila semakin kecil FDR, maka biayanya yang harus dikeluarkan oleh bank guna membiayai operasionalnya juga akan semakin kecil. Wahyuda et al., (2017) menyebut bila bank mampu memenuhi kewajibannya dalam membayar hutang bunga kepada para deposan mengindikasikan jika bank tersebut cukup likuid. Ini berarti nilai FDR yang tinggi berarti bahwa bank memiliki tingkat likuiditas yang baik. Hal tersebut didukung riset dari Lidyah et al., (2019), bahwa FDR bisa menjadi perantara bagi dominasi BOPO yang memberikan pengaruh pada daya laba. Untuk itu, H10: FDR mampu memediasi pengaruh BOPO terhadap profitabilitas Perbankan Syariah Tahun 2015-2019.

Net Operating Margin (NOM) ialah untuk menakar keahlian manajemen bank dalam menjalankan aktiva profuktifnya untuk memperoleh penghasilan bunga bersih. Dengan tingkatan ini dapat memperlihatkan bahwa keahlian bank dalam mendapatkan penghasilan kegiatannya dari uang berupa pinjaman. Hal tersebut didukung riset dari Pardede dan Pangestuti (2016) yang menjelaskan bahwa variabel LDR dapat menjadi perantara antara variabel NOM dengan variabel ROA. Sehingga H11: FDR mampu memediasi pengaruh NOM terhadap profitabilitas Perbankan Syariah Tahun 2015-2019.

Nilai FDR mampu merepresentasikan kemampuan bank dalam mengumpulkan DPK dari masyarakat. Selain itu nilai FDR juga menggambarkan tingkat intermediasi dari bank syariah (Nur \& Kusumaningtias Rohmawati, 2012). Tingginya likuiditas yang dimiliki bank bisa meningkatkan kepercayaan nasabah sehingga mempermudah bank dalam penghimpunan dana. Hal tersebut didukung riset dari Pardede \& Pangestuti (2016) yang menjelaskan bahwa variabel LDR bisa menjadi perantara antara variabel DPK dengan variabel ROA. Maka dari itu, H12: FDR mampu menjadi perantara Dana Pihak Ketiga terhadap daya keuntungan Perbankan Syariah 2015-2019.

Nilai CAR yang tinggi menandakan kemampuan bayar yang dimiliki oleh bank sangat baik. Dengan likuiditas yang tinggi, nasabah tidak khawatir dana yang ditabung tidak dapat diambil karena modal bank yang ada mampu mengcover seluruh kegiatan operasional sehingga tingkat keyakinan masyarakat terhadap bank juga akan naik. Hal tersebut didukung riset dari Pardede \& Pangestuti (2016), bahwa variabel FDR bisa menjadi perantara antara variabel CAR dengan variabel ROA. Untuk itu, H13: FDR mampu memediasi CAR terhadap daya laba Perbankan Syariah Tahun 20152019.

\section{Metode penelitian}

Data yang dipakai dalam penelitian ini ialah data sekunder yang merujuk Bank Umum Syariah yang terdaftar di OJK selama periode 2015-2019. Pengambilan sampel dilakukan dengan purposive sampling dengan tujuan untuk memperoleh sampel yang baik. Kriteria yang digunakan yaitu bank umum syariah yang menyediakan laporan keuangan secara lengkap selama tahun penelitian. Jumlah sampel yang digunakan dalam penelitian ini sejumlah 11 BUS di Indonesia yaitu Bank Muamalat 
Indonesia, Bank Victoria Syariah, Bank Rakyat Indonesia Syariah, Bank Syariah Mandiri, Bank Jabar Banten Syariah, Bank Negara Indonesia Syariah, Bank Mega Syariah, Bank Panin Dubai Syariah, Bank Bukopin Syariah, Bank Central Asia Syariah, Bank Tabungan Pensiunan Nasional Syariah yang diambil dari laporan keuangan tahunan yang tersedia di website masing-masing bank.

Model analisis yang digunakan menggunakan metode analisis regresi linear berganda data panel, dalam penelitian ini model estimasi yang dipergunakan yaitu persamaan linear. Selanjutnya dilakukan diagnosa asumsi klasik yang berupa: uji normalitas, uji multikolinearitas, uji heterokedastisitas, dan uji autokorelasi. Pengujian meliputi uji kebaikan model yaitu koefisien determinasi, uji F statistik, dan uji parsial (uji t). Pengambilan keputusan dengan menggunakan taraf signifikansi 0.05 .

Persamaan regresi dalam riset ini ialah antara lain:

Persamaan 1 FDR $=\beta_{0}+\beta_{1} \cdot \mathrm{BOPO}_{1}+\beta_{2} \cdot \mathrm{NOM}_{2}+\beta_{3} \cdot \mathrm{DPK}_{3}+\beta_{4} \cdot \mathrm{CAR}_{4}$

Persamaan 2 ROA $=\beta_{0}+\beta_{1} \cdot \mathrm{BOPO}_{1}+\beta_{2} \cdot \mathrm{NOM}_{2}+\beta_{3} \cdot \mathrm{DPK}_{3}+\beta_{4} \cdot \mathrm{CAR}_{4}+\beta_{5} . \mathrm{FDR}$

\section{Hasil dan Pembahasan}

\subsection{Hasil}

Tabel 2. Chow Test

\begin{tabular}{|l|l|l|l|}
\hline & \multicolumn{3}{l|}{ Cross-section F } \\
\hline Effects Test & Statistic & d.f. & Prob. \\
\hline Persamaan 1 & 4.347644 & $(10,40)$ & 0.0004 \\
\hline Persamaan 2 & 16.968513 & $(10,39)$ & 0.0000 \\
\hline
\end{tabular}

Sumber: Data sekunder diolah tahun 2021

Persamaan 1 Uji Chow dilakukan untuk memilih antara common effect dan fixed effect. Hasil output menunjukkan nilai Prob* $0.0004<0.05$, maka yang dipilih adalah fixed effect model.

Persamaan 2 Uji Chow dilakukan untuk memilih antara common effect dan fixed effect. Hasil output menunjukkan nilai Prob* $0.0000<0.05$, maka yang dipilih adalah fixed effect model.

Tabel 3. Hausman Test

\begin{tabular}{|l|l|l|l|}
\hline \multicolumn{4}{|l|}{ Cross-section F } \\
\hline Effects Test & Statistic & d.f. & Prob. \\
\hline Persamaan 1 & 10.100473 & 4 & 0.0388 \\
\hline Persamaan 2 & 28.843580 & 5 & 0.0000 \\
\hline
\end{tabular}

Sumber: Data sekunder diolah tahun 2021

Persamaan 1 Uji Hausman dilakukan untuk memilih antara fixed effect dan random effect. Hasil output menunjukkan nilai Prob* $0.0388<0.05$, yang dipilih adalah fixed effect model.

Persamaan 2 Uji Hausman dilakukan untuk memilih antara fixed effect dan random effect. Hasil output menunjukkan nilai Prob* $0.0000<0.05$, maka yang dipilih adalah fixed effect model.

Model Regresi Persamaan 1 sebagai berikut :

$\mathrm{FDR}=\beta_{0}+\beta_{1} \cdot \mathrm{BOPO}_{1}+\beta_{2} \cdot \mathrm{NOM}_{2}+\beta_{3} \cdot \mathrm{DPK}_{3}+\beta_{4} \cdot \mathrm{CAR}_{4}$

FDR $=62.04855-0.058775(\mathrm{BOPO})-17.45345(\mathrm{NOM})+3.189609(\mathrm{DPK})+0.126219(\mathrm{CAR})$

Model Regresi Persamaan 2 sebagai berikut :

$$
\begin{aligned}
\mathrm{ROA} & =\beta_{0}+\beta_{1} \cdot \mathrm{BOPO}_{1}+\beta_{2} \cdot \mathrm{NOM}_{2}+\beta_{3} . \mathrm{DPK}_{3}+\beta_{4} \cdot \mathrm{CAR}_{4}+\beta_{5} . \mathrm{FDR} \\
\mathrm{ROA} & =5.661414-0.073180(\mathrm{BOPO})+19.10589(\mathrm{NOM})-3.196067(\mathrm{DPK})+0.008068(\mathrm{CAR}) \\
& +0.009574(\mathrm{FDR})
\end{aligned}
$$


Uji Koefisien Determinasi $\left(R^{2}\right)$

Tabel 4. Uji R-squared

\begin{tabular}{|l|l|l|l|}
\hline \multicolumn{2}{|c|}{ Persamaan 1 } & \multicolumn{2}{c|}{ Persamaan 2 } \\
\hline R-squared & 0.891581 & R-squared & 0.996296 \\
\hline Adjusted R-squared & 0.833499 & Adjusted R-squared & 0.994102 \\
\hline
\end{tabular}

Sumber: Data Sekunder diolah, 2021

Persamaan 1 R-squared sebesar 0,90 dan Adjusted R-squared 0.85, artinya ini memperlihatkan keahlian dalam menerangkan dominasi variasi dependen senilai $85 \%$. Sisanya senilai $15 \%$ diperoleh dari variasi lain diluar penelitian.

Persamaan 2 R-squared sebesar 0,99 dan Adjusted R-squared 0.99, artinya ini memperlihatkan keahlian dalam menerangkan dominasi variasi dependen senilai $99 \%$. Sisanya senilai $1 \%$ diterangkan oleh variasi lain diluar penelitian.

Uji F

Tabel 5. Uji F

\begin{tabular}{|l|l|l|l|}
\hline \multicolumn{2}{|c|}{ Persamaan 1 } & \multicolumn{2}{c|}{ Persamaan 2 } \\
\hline F-statistic & 15.35044 & F-statistic & 453.9500 \\
\hline Prob(F-statistic) & 0.000000 & Prob(F-statistic) & 0.000000 \\
\hline
\end{tabular}

Sumber: Data Sekunder diolah, 2021

Persamaan 1 pemeriksaan ini jika dilihat dari nilai $\operatorname{prob}(F$-statistic). Merujuk pada hasil riset ini memperlihatkan jika nilai prob(F-statistic) senilai $0,000<0.05$, oleh karena itu bisa ditarik kesimpulan jika variabel independen secara bersamaan bisa mendominasii FDR.

Persamaan 2 pemeriksaan ini dengan memperhatikan nilai $\operatorname{prob}(F$-statistic). Merujuk pada hasil riset ini menjelaskan jika nilaiprob (F-statistic) senilai $0,000<0.05$, oleh karena itu bisa ditarik kesimpulan jika variabel independen secara bersamaan bisa mempunyai pengaruh pada ROA.

Uji T

Tabel 6. Uji t Parsial (Persamaan 1)

\begin{tabular}{crrrr} 
Variable & Coefficient & Std. Error & t-Statistic & Prob. \\
\hline \hline C & 62.04855 & 4.515452 & 13.74138 & 0.0000 \\
BOPO & -0.058775 & 0.010185 & -5.770579 & 0.0000 \\
NOM & -17.45345 & 2.647359 & -6.592777 & 0.0000 \\
DPK & 3.189609 & 1.334311 & 2.390453 & 0.0238 \\
CAR & 0.126219 & 0.037608 & 3.356157 & 0.0023 \\
FDR(-1) & 0.310542 & 0.056400 & 5.506028 & 0.0000
\end{tabular}

Sumber: Data Sekunder diolah, 2021

1. BOPO terhadap FDR

Dari hasil pemeriksaan didapatkan nilai daya laba 0.0000. dikarenakan nilai daya laba $<0,05(\alpha)$

serta koefisien negatif, artinya BOPO secara parsial memberikan pengaruh negatif serta substansial terhadap FDR.

2. NOM terhadap FDR

Dari hasil pemeriksaan didaptakan nilai daya laba 0.0000. Dikarenakan nilai daya laba $<0,05(\alpha)$ dan koefisien negatif, artinya NOM secara parsial memberikan pengaruh negatif serta substansial terhadap FDR.

3. DPK terhadap FDR

Dari hasil pemeriksaan didapatkan nilai daya laba 0.0238. Dikarenakan nilai daya laba $<0,05(\alpha)$ serta koefisien positif, oleh karena itu DPK secara parsial memberikan pengaruh positif serta substansial terhadap FDR. 
4. CAR terhadap FDR

Dari hasil pemeriksaan didapatkan nilai daya laba 0.0023 . Dikarenakan nilai daya laba $<0,05(\alpha)$ serta koefisien positif, oleh karena itu CAR secara parsial memberikan pengaruh positif serta substansial terhadap FDR.

Tabel 7. Uji t Parsial (Persamaan 2)

\begin{tabular}{crrrr} 
Variable & Coefficient & Std. Error & t-Statistic & Prob. \\
\hline \hline C & 5.661414 & 0.952750 & 5.942181 & 0.0000 \\
BOPO & -0.073180 & 0.002267 & -32.28251 & 0.0000 \\
NOM & 19.10589 & 2.024048 & 9.439450 & 0.0000 \\
DPK & -3.196067 & 1.710379 & -1.868630 & 0.0726 \\
CAR & 0.008068 & 0.004027 & 2.003205 & 0.0553 \\
FDR & 0.009574 & 0.007792 & 1.228646 & 0.2298 \\
ROA $(-1)$ & -0.007691 & 0.006704 & -1.147216 & 0.2614 \\
\hline \hline
\end{tabular}$==$

Sumber: Data Sekunder dolah, 2021

1. BOPO terhadap ROA

Dari hasil pemeriksaan didapatkan nilai daya laba senilai 0.0000. dikarenakan nilai daya laba < $0,05(\alpha)$ serta koefisien negatif, artinya BOPO secara parsial mempunyai pengaruh negatif serta substansial terhadap ROA.

2. NOM terhadap ROA

Dari hasil pemeriksaan didapatkan diperoleh nilai daya laba senilai 0.0000. dikarenakan nilai daya laba $<0,05(\alpha)$ serta koefisien positif, artinya NOM secara parsial mempunyai pengaruh paitif serta substansial terhadap ROA.

3. DPK terhadap ROA

Dari hasil pemeriksaan didapatkan nilai daya keuntungan senilai 0.0726. dikarenakan nilai daya keuntungan $>0,05(\alpha)$ serta koefisien positif, Oleh karena itu DPK secara parsial memberikan pengaruh positif serta tidak substansial terhadap ROA.

4. CAR terhadap ROA

Dari hasil pemeriksaan didapatkan nilai daya keuntungan 0.0553. Karena nilai daya keuntungan $>$ $0,05(\alpha)$ serta koefisien positif, oleh karena itu CAR secara parsial mempunyai pengaruh positif serta tidak substansial terhadap ROA.

5. FDR terhadap ROA

Dari hasil pemeriksaan didapatkan nilai daya keuntungan senilai 0.2298. dikarenakan nilai daya keuntungan $>0,05(\alpha)$ serta koefisien positif, oleh karena itu FDR secara parsial mempunyai pengatuh positif serta tidak signifikan terhadap ROA.

Path Analisys (Analisis Jalur)

Tabel 8. Path Analisys

\begin{tabular}{|l|l|l|c|c|c|c|c|}
\hline Variabel & X ke Y (p1) & $\begin{array}{c}\text { X ke Z } \\
(\mathrm{p} 2)\end{array}$ & $\begin{array}{c}\text { Z ke Y } \\
(\mathrm{p} 3)\end{array}$ & \multicolumn{1}{|c|}{ Sp2 } & Sp3 & $\begin{array}{c}\text { Pengaruh } \\
\text { Tidak } \\
\text { Langsung }\end{array}$ & $\begin{array}{c}\text { Pengaruh } \\
\text { Total }\end{array}$ \\
\hline BOPO & -0.073180 & -0.058775 & 0.009574 & 0.010185 & 0.007792 & -0.000562 & -0.073742 \\
\hline NOM & 19.10589 & -17.45345 & 0.009574 & 2.647359 & 0.007792 & -0.167099 & 18.938791 \\
\hline DPK & -3.196067 & 3.189609 & 0.009574 & 1.334311 & 0.007792 & 0.030537 & 3.226604 \\
\hline CAR & 0.008068 & 0.126219 & 0.009574 & 0.037608 & 0.007792 & 0.001208 & 0.009276 \\
\hline
\end{tabular}

Untuk menguji signifikansi sebagai berikut :

a. $\quad \mathrm{Sp} 2 \mathrm{p} 3=\sqrt{p 3^{2} s p 2^{2}+p 2^{2} s p 3^{2}+s p 2^{2} s p 3^{2}}$

$$
\sqrt{(-0.009574)^{2}(0.010185)^{2}+(-0.058775)^{2}(0.007792)^{2}+(0.010185)^{2}(0.007792)^{2}}
$$


$\sqrt{2.255564}=0.000474$

$\mathrm{t} 1=\frac{p 2 p 3}{s p 2 p 3}=\frac{0.000562}{0.000474}=-1.183342$

b. $\mathrm{Sp} 2 \mathrm{p} 3=\sqrt{p 3^{2} s p 2^{2}+p 2^{2} s p 3^{2}+s p 2^{2} s p 3^{2}}$

$\sqrt{(0.009574)^{2}(2.647359)^{2}+(-17.45345)^{2}(0.007792)^{2}+(2.647359)^{2}(0.007792)^{2}}$

$\sqrt{0.010484}=0.102392$

$\mathrm{t} 2=\frac{p 2 p 3}{s p 2 p 3}=\frac{-0.167099}{0.102392}=-1.631950$

c. $\quad \mathrm{Sp} 2 \mathrm{p} 3=\sqrt{p 3^{2} s p 2^{2}+p 2^{2} s p 3^{2}+s p 2^{2} s p 3^{2}}$

$$
\begin{aligned}
& \sqrt{(0.009574)^{2}(1.334311)^{2}+(3.189609)^{2}(0.007792)^{2}+(1.334311)^{2}(0.007792)^{2}} \\
& \sqrt{0,000288}=0.00816 \\
& \mathrm{t} 3=\frac{p 2 p 3}{s p 2 p 3}=\frac{0.030537}{0.00816}=3.742279
\end{aligned}
$$

d. $\quad \mathrm{Sp} 2 \mathrm{p} 3=\sqrt{p 3^{2} s p 2^{2}+p 2^{2} s p 3^{2}+s p 2^{2} s p 3^{2}}$

$$
\begin{aligned}
& \sqrt{(0.009574)^{2}(0.037608)^{2}+(0.126219)^{2}(0.007792)^{2}+(0.037608)^{2}(0.007792)^{2}} \\
& \sqrt{1.10827}=0.000108 \\
& \mathrm{t} 3=\frac{p 2 p 3}{s p 2 p 3}=\frac{0.001208}{0.000108}=11.185189
\end{aligned}
$$

1. Merujuk dari hasil $\mathrm{t}$ hitung di maka bisa diperhatikan jika $\mathrm{t}$ hitung $=-1.183342<$ dari $\mathrm{t}$ tabel dengan tingkat substansial 0.05 , atau $5 \%$ yaitu 1.67655 , oleh karena itu bisa ditarik kesimpulan jika FDR tidak menjadi perantara bagi dominasi BOPO terhadap ROA.

2. Merujuk pada hasil t hitung diatas, bisa diperhatikan jika t hitung $=-1.6319500<$ dari $t$ tabel dengan tingkat substansial 0.05 , atau 5\% ialah 1.67655 . Oleh karena itu bisa ditarik kesimpulan FDR tidak menjadi perantara dominasi NOM terhadap ROA.

3. Merujuk pada hasil $\mathrm{t}$ hitung di atas, maka bisa diperhatikan jika $t$ hitung $=3.742279>$ dari $t$ tabel dengan tingkat substansial 0.05 , atau $5 \%$ yaitu 1.67655 . Oleh karena itu bisa ditarik kesimpulan jika FDR menjadi perantara dan dominasi DPK terhadap ROA

4. Merujuk dari hasil $t$ hitung di atas, maka bisa diperhatikan jika $t$ hitung $=11.185189>$ dari $t$ tabel dengan tingkat signifikan 0.05 , atau 5\% yaitu 1.67655. Oleh karena itu bisa ditarik kesimpulan jika FDR menjadi perantara dominasi CAR terhadap ROA.

\subsection{Pembahasan}

\subsubsection{BOPO dan Financing to Deposit Ratio}

Berdasarkan hasil uji statistik fixed effect model, diketahui nilai koefisien -0.058775, dengan probabilitas 0,0000 $(<0,05)$. Maka dapat ditarik kesimpulan jika BOPO naik sebesar 1 satuan, maka FDR akan turun sebanyak -0.058775. sehingga ini membuktikan BOPO memiliki dampak negatif serta signifikan terhadap FDR. Hasil riset ini sesuai dengan riset yang telah dilakukan oleh Ichwan, (2017) serta_Kartini \& Nuranisa, (2018) yang menegaskan bahwa tingginya BOPO akan menyebabkan penurunan FDR secara signifikan. Hal serupa dikemukakan oleh Kartini \& Nuranisa, (2018) yang menegaskan jika BOPO memilik efek negatif terhadap FDR.

Rasio biaya operasional terhadap pendapatan operasional digunakan untuk mengukur efisiensi usaha bank. Ketika BOPO tinggi maka suku FDR akan turun karena akan mengurangi dana yang dialokasikan karena biaya operasional yang kurang efisien. Biaya opersanional yang tinggi menunjukkan kurangnya efisiensi dalam mengelola dana oleh pihak manajemen, sehingga dana yang 
dikeluarkan untuk membayaran tagihan akan membengkak. Hal tersebut menyebabkan bank terlalu banyak mengeluarkan, maka ketersediaan dana akan menurun dan bank dinyatakan tidak liquid.

\subsubsection{Net Operating Margin dan Financing to Deposit Ratio}

Berdasarkan hasil uji statistik fixed effect model, diketahui nilai koefisien -0.058775, dengan probabilitas 0,0000 $(<0,05)$. Maka dapat ditarik kesimpulan jika BOPO naik sebesar 1 satuan, maka FDR akan turun sebanyak -0.058775. sehingga ini membuktikan BOPO memiliki dampak negatif serta signifikan terhadap FDR. Hasil riset ini sesuai dengan riset yang telah dilakukan oleh Mayasari, (2019) serta Hakim, (2016). Didukung oleh riset Parinsi, (2016) yang menegaskan BOPO memiliki dampak negatif kepada FDR.

NOM menggambarkan bank dapat memperoleh keuntungan dari asset produktifnya. NOM yang tinggi menegaskan bahwa bank dapat menjalankan bisnisnya dengan optimal, ini dibuktikan dengan asset yang dimiliki mampu menciptakan keuntungan. Hal ini berarti bank lebih banyak mengandalkan asset produktif dalam memperoleh keuntungan, sehingga likuidasi perusahaan menurun. Tingginya NOM menunjukkan jika pemanfaatan asset dalam kegiatan bisnis dilakukan dengan intensitas tinggi, sehingga yang tersedia akan menurun karena telah diinvestasikan, maka secara signifikan akan menurunkan likuiditas bank itu sendiri.

\subsubsection{Dana Pihak Ketiga dan Financing to Deposit Ratio}

Jika dilihat dari hasil linear regresi berganda sesuai dengan tabel hasil uji FEM pada persamaan pertama memperoleh hasil koefisien 3.189609 dengan probabilitas 0.000. Berdasarkan perolehan probabilitas ditemukan bahwasannya probabilitas lebih kecil dibandingkan substansial senilai 0.05 . Oleh karena itu bisa ditarik kesimpulan hipotesis 3 tidak diterima dan bisa disimpulkan apabila variable DPK mempunyai pengaruh positif terhadap likuiditas secara signifikan. Hasil riset ini sesuai dengan riset yang telah dilakukan oleh Enny, (2016) serta Susilowati, (2016) yang menegaskan jika tingginya DPK akan menaikkan FDR secara signifikan. Kartini \& Nuranisa, (2018) juga menyatakan DPK berdampak negatif terhadap FDR dan mendudukung hasil penelitian ini.

Dana pihak ketiga (DPK) dapat digunakan sebagai tolak ukur untuk menilai kemampuan bank dalam memenuhi kebutuhan likuiditas dengan menarik dana dari pihak ketiga dengan perangkat perbankan likuid yang tersedia. Semakin tinggi indikatornya, semakin baik status likuiditas bank terkait. Dana pihak ketiga menjadi salah satu alasan utama menjaga tingkat likuiditas bank. Dana simpanan nasabah adalah dana yang diterima bank pada saat melakukan fungsi intermediasi, artinya dengan bertambahnya simpanan bank maka likuiditasnya akan meningkat.

\subsubsection{Capital Adequacy Ratio dan Financing to Deposit Ratio}

Berdasarkan hasil linear regresi berganda sesuai dengan tabel hasil uji FEM pada persamaan pertama memperoleh hasil koefisien 0.126219 dengan probabilitas 0.0023 Berdasarkan perolehan probabilitas ditemukan bahwasannya probabilitas < jika diperbandingkan dengan substansial senilai 0.05 . oleh karena itu bisa ditarik kesimpulan jika hipotesis 4 diterima serta bisa diambil kesimpulan apabila variable CAR mempunyai pengaruh positif terhadap likuiditas signifikan. Hasil riset ini sesuai dengan riset yang telah dilakukan oleh Agustini \& Wardana, (2018) dan Ardiansari et al., (2016) serta Utami $\underline{\text { \& Muslikhati, (2019) }}$

Capital adequacy ratio (CAR) adalah indeks yang mengukur rasio kecukupan modal dari aset yang mendukung bank yang mengandung atau memiliki risiko. Rasio kecukupan modal merupakan indeks yang mengukur kemampuan bank dalam menghimpun dana untuk investasi komersial dan beradaptasi dengan risiko operasional bank. CAR berarti bank memiliki modal yang cukup untuk likuiditas.

\subsubsection{Financing to Deposit Ratio dan Profitabilitas}

Berdasarkan hasil linear regresi berganda sesuai dengan tabel hasil uji FEM pada persamaan pertama memperoleh hasil koefisien 0.009574 dengan probabilitas 0.2298 . Berdasarkan perolehan probabilitas ditemukan bahwasannya probabilitas $>$ jika dibandingkan substansial $=0.05$. Oleh karena itu bisa ditarik kesimpulan jika hipotesis 5 ditolak dan bisa ditarik kesimpulan bahwa variable FDR 
mempunyai pengaruh positif terhadap daya keuntungan tidak signifikan. Hasil riset ini sesuai dengan riset yang telah dilakukan oleh Henny \& Lestari, (2018) dan Syakhrun et al., (2019) serta Simatupang \& Franzlay, (2016).

Hal ini menunjukkan bahwa tingkat likuiditas tidak akan mempengaruhi profitabilitas, karena lambatnya penggunaan kas dan pemanfaatan asset produktif berdampak negatif pada pengembalian aset yang ada, pengurangan operasi dan pengurangan kegiatan usaha, dan hasilnya terbukti tidak mempengaruhi profitabilitas perusahaan. Meskipun tingkat likuiditas dalam bank terjaga dengan baik, tetapi disisi lain bank tidak mampu mengelola kelebihan tersebut maka keuntungan yang ditargetkan tidak akan terpenuhi.

\subsubsection{BOPO dan profitabilitas}

Merujuk dari hasil linear regresi berganda sesuai dengan tabel hasil uji FEM pada persamaan pertama memperoleh hasil koefisien --0.073180 dengan probabilitas 0.000 . Berdasarkan perolehan probabilitas ditemukan bahwasannya probabilitas < jika diperbandingkan secara substansial senilai 0.05 . Oleh karena itu bisa ditarik kesimpulan dari hipotesis 6 diterima serta bisa ditarik kesimpulan bahwa variable BOPO mempunyai pengaruh negatif terhadap profitabilitas secara signifikan. Hasil riset ini sesuai dengan riset yang telah dikerjakan Ichwan (2017) yang menunjukkan bahwa variable BOPO mempunyai pengaruh negatif serta substansial. Didukung oleh hasil riset Hermina \& Suprianto, (2016) serta Syah, (2018)

BOPO ialah perbedaan antara beban operasional dengan pendapatan operasional. Rasio ini dipakai untuk menakar tingkat keefisiensian bank saat dilakukan operasionalnya. Bank dikatakan efisien apabila bank mampu memperkecil biaya operasi serta menaikkan penghasilan operasi untuk meningkatan profit bank yang besar dan bisa menghindari dari keadaan bank yang bermasalah. Maka semakin kecil BOPO maka kinerja bank dalam mengerjakan aktivitasnya akan meningkat dan begitupun sebaliknya.

\subsubsection{Net Operating Margin dan profitabilitas}

Merujuk hasil linear regresi berganda sesuai dengan tabel hasil uji FEM pada persamaan pertama memperoleh hasil koefisien 19.10589 dengan probabilitas 0.0000. Berdasarkan perolehan probabilitas ditemukan bahwasannya probabilitas < jika dibanding substansial senilai 0.05. oleh karena itu bisa ditarik kesimpulan jika hipotesis 7 bisa masuk dan bisa ditarik kesimpulan apabila variable NOM mempunyai pengaruh positif terhadap profitabilitas secara signifikan. Hasil riset ini sesuai dengan riset yang telah dikerjakan oleh Yusuf \& Wahyuni, (2017) dan Yusuf, (2017).

NOM ialah tingkatan rentabilitas pada bank Syariah untuk melihat keahlian aktiva produktif dalam memperoleh keuntungan. Semakin besar NOM dalam suatu bank maka semakin tinggi penghasila bersih suatu bank yang berasal dari aktiva produktifnya, sehingga laba bank mengalami kenaikan. NOM membuktikkan jika bank mampu memanfaatkan potensi pengalokasian dana yang tersedia, sehingga mampu memberikan keuntungan secara optimal. Dengan terjaganya kualitas pengaolasian dana, akitivas bisnis yang dilakukan bank telah berada pada jalur yang benar. Tujuan semua kegiatan bisnis adalah untuk memperoleh keuntungan yang besar dan tentunya harus ditunjang oleh kompetensi dalam mengatur dan mengawasi setiap kegiatan yang memerlukan modal yang berasal dari asset bank.

\subsubsection{Dana Pihak Ketiga dan profitabilitas}

Jika merujuk pada hasil linear regresi berganda sesuai dengan tabel hasil uji FEM pada persamaan pertama memperoleh hasil koefisien -3.196067 dengan probabilitas 0.0726. Berdasarkan perolehan probabilitas ditemukan bahwasannya probabilitas > jika dibanding substansial senilai 0.05. Oleh karena itu bisa ditarik kesimpulan hipotesis 8 tidak diterima serta bisa ditarik kesimpulan bahwa variable DPK mempunyai pengaruh negatif terhadap daya keuntungan tidak signifikan. Hasil riset ini sesuai dengan riset yang telah dilakukan oleh Sukma et al., (2019) dan Pardede \& Pangestuti, (2016) serta Setiawan \& Indriani, (2016). 
Dana pihak ketiga merupakan dana yang diperoleh dari masyarakat baik itu dari tabungan, deposito ataupun simpanan serta pinjaman dari bank lain yang kemudian dihimpun oleh bank. Uang yang dihimpun akan dikembangkan secara maksimal oleh bank untuk memperoleh laba dengan cara menyalurkan kredit yang diberikan kepada masyarakat. Karena semakin optimal dalam pengelolaan DPK maka tingkat profitabilitas yang di dapat juga akan semakin meningkat. Namun jika dana tersebut tidak dikelola dengan baik maka sebesar apapun DPK yang dimiliki oleh bank tidak akan berdampak terhadap profitabilitas yang diperoleh. Dalam penyaluran dana pihak ketiga harus mencermati aspek-aspek yang dapat menghambat keberlangsungan investasi. Jika dalam implementasinya terjadi pembiayaan yang macet maka akan merugikan bank, alih-alih untuk mendapatkan keuntungan yang signifikan.

\subsubsection{Capital Adequacy Ratio dan profitabilitas}

Jika merujuk pada hasil linear regresi berganda sesuai dengan tabel hasil uji FEM pada persamaan pertama memperoleh hasil koefisien 0.008068 dengan probabilitas 0.0553 . Berdasarkan perolehan probabilitas ditemukan bahwasannya probabilitas > jika dibanding substansial senilai 0.05 . Oleh karena itu bisa ditarik kesimpulan jika hipotesis 9 ditolak serta bisa ditarik kesimpulan bahwa variable CAR mempunyai pengaruh positif tidak signifikan terhadap profitabilitas secara substansial. Hasil riset ini sejalan dengan riset yang telah dikerjakan oleh Harianto, (2017), Utami \& Muslikhati, (2019) serta Pinasti \& Mustikawati, (2018).

Hal ini dikarenakan ketentuan CAR Bank Indonesia yang mengatur CAR bank minimal 8\%. Kondisi ini berarti bank selalu menyatakan bahwa aturan indeks kecukupan modal (CAR) selalu dapat dipatuhi. Namun, bank cenderung mengendalikan CAR mereka tidak lebih dari 8\%, karena itu berarti tidak ada investasi modal atau bahkan pemborosan, karena ekuitas bank sebenarnya adalah kepercayaan, dan 8\% CAR hanya disediakan oleh Bank Indonesia untuk menyesuaikan diri menurut Bisnis Perbankan Internasional dari Bank for International Settlements

\subsubsection{BOPO dan ROA melalui Financing to Deposit Ratio}

Jika merujuk pada hasil $\mathrm{t}$ hitung di atas, apabila $\mathrm{t}$ hitung $=-1.183342<$ dari $\mathrm{t}$ tabel dengan tingkat substansial $=0.05$, atau 5\% yaitu 1.67655 . Oleh karena itu bisa ditarik kesimpulan bahwa FDR tidak bisa menjadi perantara dari dominasi BOPO terhadap ROA. Hasil riset ini mendukung penelitian (Fitria \& Widiati, 2018).

Alasan dari hasil penelitian ini ada, operasional yang dilakukan oleh bank dalam rangka mendapatkan keuntungan terlalu tinggi. Efisiensi yang harapkan tidak dapat terpenuhi. Tingkat likuiditas yang sebenarnya merupakan hal yang harus diperhatikan oleh bank tidak mampu menjembatani dalam hal pengurangan biaya operasional. Menurut peneliti, hal tersebut bisa terjadi karena kurangnya efisiensi dari pihak menajemen dalam menjalankan kegiatan bisnis, sehingga biaya yang ditimbulkan cukup tinggi. Selanjutnya tingkat likuiditas yang diharapkan juag tidak tercapai dikarakan pengeluaran dalam operasional perusahaan yang menuntut agar semua terpenuhi sehinggi likuidasi perusahaan tidak terpenuhi.

\subsubsection{Net Operating Margin dan profitabilitas melalui Financing to Deposit Ratio}

Jika merujuk pada hasil $t$ hitung di atas, bisa diperhatikan apabila $t$ hitung $=-1.6319500<$ dari $t$ tabel dengan tingkat substansial senilai 0.05 yaitu 1.67655 Oleh karena itu bisa ditarik kesimpulan apabila FDR tidak menjadi perantara dominasi antara NOM terhadap ROA. Hasil riset ini tidak mendukung penelitian Pardede \& Pangestuti, (2016) yang menunjukkan bahwa FDR dapat memediasi NOM.

Semakin tinggi tingkat rasio NOM maka semakin tinggi pula rasio FDR. Begitu sebaliknya, apabila semakin rendah rasio NOM maka pendapatan bersih dari laba akan semakin kecil. Hal ini disebabkan NOM sendiri ialah rasio yang hubungannya dengan keahlian sebuah bank dalam mengerjakan manajemen. Manajemen ini dibutuhkan untuk mengerjakan aktiva produktif, yang kemudian akan mendapatkan keuntungan atau pembagian dari hasil bersih. Disisi rasio NOM yang tinggi akan menurunkan tingkat likuidasi bank. Hal terbebut bisa terjadi dikarenakan asset yang dimiliki oleh 
bank terlalu dimanfaatkan terlalu berlebihan, sehingga target investasi yang terlalu tinggi menyebabkan penurunan kualitas likuidasi bank itu sendiri.

\subsubsection{Dana Pihak Ketiga dan profitabilitas yang dimediasi oleh Financing to Deposit Ratio}

Jika dilihat dari hasil $t$ hitung di atas, maka bisa diperhatikan apabila $t$ hitung $=3.742279>$ dari $t$ tabel dengan tingkat substansial senilai 0.05 yaitu 1.67655 . Oleh karena itu bisa ditarik kesimpulan apabila FDR memberi pentara dominasi DPK terhadap ROA. Hasil riset ini mendukung penelitian Pardede \& Pangestuti, (2016) yang menjelaskan apabila FDR bisa menjadi perantara antara DPK terhadap ROA.

Jika DPK dalam sebuah bank itu semakin tinggi, maka kemampuan pengelolaan bank syariah untuk mengembangkan uangnya dalam bentuk pembiayaan juga semakin tinggi. Apabila jumlah DPK yang diperoleh tinggi tidak seimbang dengan kelncaran penyaluran kredit memungkinkan bank akan menjalani tingkat kerugiannya. Karena penghasilan bunga yang berasal dari pengembangan kredit kepada debitur tidak bisa melunasi biaya bunga yang harus dilunasi kepada debitur. Tingginya DPK menunjukkan jika ketersediaan dana bank terjamin dan bank dinaytakan liquid. Maka dari itu jika bank akan melakukan investasi dalam bentuk apapun tidak akan mengalami kendala dalam hal keunagan karena memiliki dana yang cukup dan likuiditas yang memadai.

\subsubsection{Capital Adequacy Ratio dan profitabilitas yang dimediasi oleh Financing to Deposit Ratio} Jika dilihat dari hasil $\mathrm{t}$ hitung di atas, maka bisa diperhatikan apabila $\mathrm{t}$ hitung $=11.185189>$ dari $\mathrm{t}$ tabel dengan tingkat substansial 0.05 , yaitu 1.67655. Oleh karena itu bisa ditarik kesimpulan apabila FDR menjadi perantara substansial CAR terhadap ROA. Hasil riset ini mendukung penelitian Pardede \& Pangestuti, (2016) serta Ni'mah, (2019) yang menunjukkan bahwa FDR dapat memediasi CAR terhadap ROA. Hal serupa juga dikemukakan oleh Hasanah, (2019).

Semakin tinggi tingkat rasio CAR maka semakin kuat bank untuk bertanggung jawab pada aktiva prduktif yang berisiko pada bank. Tingkat rasio CAR yang tinggi dapat berpengaruh aktivitas pembiayaan dan tingkat likuiditasnya. Begitu sebaliknya dengan tingkat rasio FDR, apabila tingkat rasio FDR semakin tinggi, maka kemampuan likuiditasnya semakin rendah. Ketersediaan modal yang dimiliki oleh bank tidak akan menghalangi dalam tujuan untuk melakukan investasi, sehingga target laba bisa terpenuhi. Selain itu tingkat lukuiditas mendukung kegiatan investasi tanpa harus memikirkan dana yang diperlukan baik untuk disalurkan maupun untuk menjaga ketersediaan dalam bank.

\section{Kesimpulan}

Hasil penelitian menunjukkan bahwa variable BOPO NOM tidak berpengaruh terhadap FDR. Variable DPK CAR berpengaruh positif signifikan terhadap FDR. Variable FDR berpengaruh positif terhadap profitabilitas. Variable BOPO DPK tidak berpengaruh terhadap profitabilitas. Variable NOM berpengaruh positif signifikan terhadap profitabilitas. Variable CAR tidak berpengaruh terhadap profitabilitas. FDR mampu menjadi perantara pengaruh DPK dan CAR namun tidak mampu menjadi perantara pengaruh BOPO NOM. Hasil riset bisa jadi acuan bagi pihak bank syariah dalam mengevaluasi kebijakan dan keputusan lebih lanjut dalam mengembangkan bisnisnya.

\section{Limitasi dan Studi Lanjutan}

Pada penelitian ini yang menjadi limitasi atau kelemahan adalah kurangnya data yang diperoleh sehingga memiliki keterbatasan pada saat proses penelitian. Penambahan jumlah sampel dan jumlah periode penelitian juga sangat disarankan untuk mendapatkan penemuan yang lebih baik, maksimal dan akurat.

\section{Ucapan Terima Kasih}

Terimaksih kepada kedua orang tua dan teman-teman yang sudah membantu dan mendoakan, pemberian semangat dan dukungan selama menyelesaikan penelitian ini. Karena tanpa adanya doa, dukungan dan bantuan dari berbagai pihak, penulisan ini akan sulit terselesaikan. 


\section{Referensi}

A'la, A. M., \& Imron, M. (2015). Pengaruh Financing to Deposit Ratio (FDR) Terhadap Return on Asset (ROA) dengan Variabel Intervening Penempatan Dana pada Sertifikat Bank Indonesia Syariah (SBIS) Pada Bank Syariah di Indonesia. Jurnal Ekonomi Syariah Teori Dan Terapan, 1(8), 592. https://doi.org/10.20473/volliss20148pp592-609

Achmad. (2018). Efek Capital Adequacy Ratio, Non Performing Financing, dan Operational Effeciency Ratio Atas Return on Asset Pada Bank Umum Syariah Milik Negara. At-Taradhi: Jurnal Studi Ekonomi, 9(2), 119-126. https://doi.org/10.18592/at-taradhi.v9i2.2514

Agustini, N. P. A. R., \& Wardana, I. M. (2018). Pengaruh Profitabilitas, Risiko Kredit, Likuiditas, Dan Efisiensi Operasional Terhadap Kecukupan Modal Pada Bpr Kabupaten Klungkung. E$\begin{array}{llll}\text { Jurnal Manajemen Universitas } & \text { Udayana, }\end{array}$ https://doi.org/10.24843/ejmunud.2018.v07.i10.p20

Almila, \& W, H. (2005). Analisis Rasio CAMEL terhadap Prediksi Kondisi Bermasalah pada Lembaga Perbankan Periode 2000-2002. Jurnal Akuntansi Dan Keuangan, 7(2), 951-952.

Almunawwaroh, M., \& Marliana, R. (2018). Pengaruh CAR,NPF Dan FDR terhadap Profitabilitas Bank Syariah Di Indonesia. Amwaluna: Jurnal Ekonomi Dan Keuangan Syariah, 2(1), 1-17. https://doi.org/10.29313/amwaluna.v2i1.3156

Ardiansari, A., Manajemen, J., Ekonomi, F., Semarang, U. N., \& Artikel, I. (2016). Pengaruh Dana Pihak Ketiga, Non Performing Financing, Capitaladequacy Ratio dan Return on Asset, terhadap Tingkat Likuiditas. Management Analysis Journal, 5(1), 7-16. https://doi.org/10.15294/maj.v5i1.5573

Ariyanti, I., Dhiana, P., \& Ari Pranaditya. (2017). Pengaruh CAR, NPF, NIM, BOPO, Dan DPK Terhadap Profitabilitas Dengan FDR Sebagai Variabel Intervening (Studi Kasus Perbankan Umum Syariah Tahun 2011-2014). Ekonomi - Akuntansi, 1-15.

Cholida, N., \& Sri, H. (2016). Pengaruh Capital Adequacy Ratio (CAR), Beban Operasional Pendapatan Operasional (BOPO), Return On Asset (ROA) dan Net Interest Margin (NIM) Terhadap Financing Deposit Ratio (FDR) di PT. BPRS Bhakti Sumekar Sumenep (Periode 2011-2015). Jurnal Ekonomi Dan Perbankan Syariah, 3(1).

Damayanti, P., \& S, D. A. M. (2012). Analisis Pengaruh Ukuran (SIZE), Capital Adequacy Ratio (CAR), Pertumbuhan Deposit, Loan To Deposit Ratio (LDR), Terhadap Profitabilitas Perbankan Go Public Di Indonesia Tahun 2005-2009 (Studi Empiris Perusahaan Perbanka Yang Terdaftar Di BEI). Jurnal Ilmiah Manajemen dan Akuntansi Terapan (JIMAT), 3(2), 45-54.

Enny, S. (2016). Pengaruh Dana Pihak Ketiga ( DPK ), Capital Adequacy Ratio ( CAR ), dan Non Performing Financing ( NPF ) terhadap Likuiditas Perbankan Syariah di Indonesia Periode 2011-2015.

Fikriati, K. N. (2016). Analisis Pengaruh Dana Pihak Ketiga (DPK), Non Performing Financing (NPF), dan Inflasi Terhadap Financing to Deposit Ratio (FDR) Bank Pembiayaan Rakyat Syariah (BPRS) di Indonesia Periode 2010-2013.

Fitria, L. N., \& Widiati, P. K. (2018). Analisis Pengaruh Rasio Keuangan dan Dana Pihak Ketiga Terhadap Profitabilitas Melalui Financing To Deposit Ratio Sebagai Variabel Intervening Pada Perbankan Syariah. Seminar Nasional Dan Call for Paper: Manajemen, Akuntansi Dan Perbankkan 2018, 679-689.

Hakiim, N. (2018). Pengaruh Internal Capital Adequency Ratio (CAR), Financing to Deposit Ratio (FDR), dan Biaya Operasional Per Pendapatan Operasional (BOPO) dalam Peningkatan Profitabilitas Industri Bank Syariah di Indonesia. Mega Aktiva: Jurnal Ekonomi Dan Manajemen, 7(1), 1. https://doi.org/10.32833/majem.v7i1.55

Hakim, M. N. (2016). Pengaruh DPK, kewajiban, pembiayaan, BOPO daN NIM terhadap likuiditas BUS devisa di Indonesia (periode 2011-2015). In Skripsi.

Harianto, S. (2017). Rasio Keuangan dan Pengaruhnya terhadap Profitabilitas pada Bank Pembiayaan Rakyat Syariah. Esensi, 7(1), 41-48. https://doi.org/10.15408/ess.v7i1.4076

Harun, U. (2016). Pengaruh Ratio-Ratio Keuangan CAR, LDR, NIM, BOPO, NPL Terhadap ROA. Jurnal Riset Bisnis Dan Manajemen, 4(1), 67-82.

Hasanah, E. M. (2019). Pengaruh Capital Adequacy Ratio (CAR) dan Non Performing Financing (NPF) terhadap Profitabilitas (ROA) dengan Financing to Deposit Ratio (FDR) Sebagai Variabel Intervening pada Bank Umum Syariah (Periode 2012-2016). Skripsi. 
https://doi.org/10.19109/intelektualita.v8i1.4223

Hasbidin. (2017). Pengaruh NPF \& Biaya Opersional Per- Pendapatan Operasional terhadap FDR dan Dampaknya pada Profitabilitas Perbankan Syariah. Jurnal Hukum Ekonomi Syariah, III(01), 135-153.

Henny, M. M. P., \& Lestari, S. (2018). Pengaruh Likuiditas terhadap Profitabilitas Perusahaan Manufaktur yang Terdaftar di Bursa Efek Indonesia. Kompetensi - Jurnal Manajemen Bisnis, 13(1). https://doi.org/10.22216/benefita.v3i2.3173

Hermina, R., \& Edy, S. (2014). Analisis Pengaruh CAR, NPL, LDR dan BOPO Terhadap Profitabilitas (ROE) pada Bank Umum Syariah. Jurnal Akuntansi Indonesia, 3(2), 129-142. http://jurnal.unissula.ac.id/index.php/jai/article/view/901

https://www.ojk.go.id/id/kanal/syariah/data-dan-statistik/statistik-perbankan-syariah/Pages/StatistikPerbankan-Syariah---Desember-2020.aspx

Husaeni, U. A. (2017). Analisis Pengaruh Dana Pihak Ketiga dan Non Performing Financing Terhadap Return On Asset Pada BPRS Di Indonesia. Equilibrium: Jurnal Ekonomi Syariah, 5(1), 1-16. https://doi.org/10.21043/equilibrium.v5i1.2462.CITATIONS

Ichwan, S. F. M. (2017). Analisis Faktor-Faktor Yang Mempengaruhi Profitabilitas Perbankan Syariah Di Indonesia Periode 2014 - 2016. Jurnal Ilmiah Ekonomi Islam, 1-19.

Jannah, M., \& Gunarso, P. (2020). Pengaruh Non Performing Financing ( NPF ) Dan Beban Operasional Pendapatan Operasional ( BOPO ) Terhadap Financing Deposit Ratio ( FDR ) Di Bank Syariah Indonesia. Journal Homepage: Www.Jurnal.Unmer.Ac.Id, 1-17.

Jyana, O. R., \& Affandi, A. (2019). Dana Pihak Ketiga, Kecukupan Modal, Risiko Kredit, Dan Nilai Tukar Terhadap Profitabilitas. Jurnal Riset Akuntansi Kontemporer, 11(2), 69-77.

Kartini, \& Nuranisa, A. (2016). Pengaruh Capital Adequacy Ratio (CAR), Non Performing Loan (NPL), PertumbuhanDana Pihak Ketiga (DPK), Biaya Operasional terhadap Pendapatan Operasional (BOPO)Terhadap Likuiditas Yang Diukur Dengan Loan to Deposit Ratio Pada Perusahan Perbankan Yang Tercat. Unisia, XXXVI. http://library1.nida.ac.th/termpaper6/sd/2554/19755.pdf

Kartini, \& Nuranisa, A. (2018). Pengaruh Capital Adequacy Ratio (CAR), Non Performing Loan (NPL), PertumbuhanDana Pihak Ketiga (DPK), Biaya Operasional terhadap Pendapatan Operasional (BOPO)Terhadap Likuiditas Yang Diukur Dengan Loan to Deposit Ratio Pada Perusahan Perbankan Yang Tercat. Unisia, 36(81).

Kasmir. (2014). Analisis Laporan Keuaangan. Rajawali Pres.

Lidyah, R., R, O. S., \& Dkk. (2019). Pengujian Financing To Deposit Ratio Sebagai Mediasi Antara Pembiayaan, Non Performing Financing Dan Biaya Operasional Pendapatan Pada Bank Umum Syariah Di Indonesia. I-Finance, 05(02), 181-200.

Lukman, D. (2009). Manajemen Perbankan (edisi 2). Ghalia Indonesia.

Maulana, F., Irawan, Y., \& Suip, M. (2019). Pengaruh BOPO , CAR , SBIS Dan Kurs Terhadap Profitabilitas Pada Bank Umum Syariah Di Indonesia. Proceeding Seminar Nasional Politeknik Negeri Lhokseumawe, 3(1), 72-76.

Mayasari, A. (2019). Analisis Pengaruh Sertifikat Bank Indonesia Syariah (Sbis), Inflasi, Dan Net Interest Margin (Nim) Terhadap Kinerja Keuangan Dengan Financing To Deposit Ratio (Fdr) Sebagai Variabel Intervening Pada Bank Umum Syariah Di Indonesia Periode 2014 - 2018. INSTITUT AGAMA ISLAM NEGERI (IAIN) SALATIGA.

Muliawati, S., \& Khoiruddin, M. (2015). Faktor-Faktor Penentu Profitabilitas Bank Syariah Di Indonesia.

Musa, A. D. L., Alam, S., \& Munir, A. R. (2019). Analisis CAR, NPL, NIM, ROA Terhadap LDR Pada P.T. Bank Bumn (PERSERO) Di Indonesia. Jurnal Economix, 7, 1-8.

Ni'mah, S. I. (2019). PENGARUH CAR DAN NPF TERHADAP PROFITABILITAS DENGAN FDR SEBAGAI VARIABEL INTERVENING PADA PERBANKAN SYARIAH DI INDONESIA (Studi Empiris pada Bank Umum Syariah yang Terdaftar di Otoritas Jasa Keuangan Periode 2016-2018). Skripsi.

Nur, S., \& Kusumaningtias Rohmawati. (2012). Determinan Financing To Deposit Ratio Determinan Financing To Deposit Ratio. Jurnal Ilmu Manajemen, 1(4).

Pardede, D. N., \& Pangestuti, I. R. D. (2016). Analisis Pengaruh CAR, Dana Pihak Ketiga (DPK), NIM, Dan LDR Terhadap Profitabilitas Perbankan Dengan LDR Sebagai Variabel Intervening. 
Dipone goro Journal of Management, 5(3), 1-13. http://ejournal-s1.undip.ac.id/index.php/dbr

Parenrengi, S., \& Tyahya Whisnu H. (2018). Pengaruh Dana Pihak Ketiga, Kecukupan Modal Dan Penyaluran Kredit Terhadap Profitabilitas Bank. Jurnal Manajemen Strategi Dan Aplikasi Bisnis, 1(1), 9-18. https://doi.org/10.36407/jmsab.v1i1.15

Parinsi, E. M. . (2016). Analisis Pengaruh Car, Npl, Nim, Dan Roa Tehadap Likuiditas Pada Bbank Bumn (Persero) Di Indonesia Periode 2007-2011. Skripsi Unhas Makasar, 86.

Peling, I. A. A., \& Sedana, I. B. P. (2018). Pengaruh LDR, NPL, Dan BOPO Terhadap Profitabilitas Pada PT. BPD Bali Periode Tahun 2009-2016. E-Jurnal Manajemen Unud, 7(6), 2999-3026.

Pinasti, W. F., \& Mustikawati, R. I. (2018). Pengaruh CAR, BOPO, NPL, NIM Dan LDR Terhadap Profitabilitas Bank Umum Periode 2011-2015. Nominal, Barometer Riset Akuntansi Dan Manajemen, 7(1). https://doi.org/10.21831/nominal.v7i1.19365

Prasaja, M. (2020). Analisis Pengukuran Rasio Keuangan dan Makro Ekonomi Terhadap Profitabilitas Bank Syariah. Annual Conference On IhtifaZ: Islamic Economics, Finance, and Banking, 249-265.

Pratiwi, L. P. S. W., \& W, N. L. P. (2016). Pengaruh CAR, BOPO, NPL Dan LDR Terhadap Profitabilitas. E-Jurnal Manajemen Universitas Udayana, 5(4), 255168.

Prihatiningsih. (2012). Pengaruh DPK, Capital Adequecy Ratio (CAR), Imbal Hasil Sertifikat Bank Indonesia Syariah (SBIS), Imbal Hasil Sertifikat Investasi Mudharabah Antar Bank Syariah (SIMA), dan Non Performing Financing (NPF) terhadap Financing to Deposit Ratio (FDR) (Studi P. Eprints Undip.

Purbasari, R. N. (2018). Pengaruh KAP, CAR, SIZE, Dan NOM Terhadap Financing To Deposit Ratio (FDR) Pada Bank Umum Syariah Di Indonesia Periode 2012-2016. In Jakarta: Fakultas Ekonomi dan Bisnis UIN Syarif Hidayatullah Jakarta (Vol. 2).

Reviyana, \& Lestari, W. (2016). Pengaruh CAR, NPL, BOPO, dan LDR Terhadap Profitabilitas Pada PT Bank Lampung Tbk Teluk Betung Periode 2010 2014. Jurnal Riset Akuntansi Dan Manajemen, 5(2).

Rivai, Veitzhal, \& Dkk. (2007). Bank and Financial Institution Management Conventional and Sharia System. jakarta: PT Raja Grafindo Persada. PT Rajagrafindo Persada.

Santoso, A. L., \& Sukihanjani, T. (2016). Analisis Faktor-Faktor Yang Mempengaruhi Likuiditas Perbankan Di Indonesia. Jurnal Ekonomi Universitas Sebelas Maret, 221-231.

Saputra, I. M. H. E., \& Budiasih, I. G. A. N. (2016). Pengaruh Kecukupan Modal, Risiko Kredit, Biaya Operasional Pendapatan Operasional Pada Profitabilitas Bank. E-Jurnal Akuntansi Universitas Udayana, 3, 2363-2378.

Sengkey, J. I. B., Murni, S., E, T. J., Manajemen, J., Sam, U., \& Manado, R. (2018). Analisis Faktor Faktor yang Mempengaruhi Risiko Likuiditas Bank (Studi Kasus pada Bank Umum Swasta Nasional yang Terdaftar Di Bei Periode 2012-2015). Jurnal EMBA: Jurnal Riset Ekonomi, Manajemen, Bisnis Dan Akuntansi, 6(4).

Setiawan, L. (2015). Pengaruh Rasio CAMEL Terhadap Kinerja Keuangan Perbankan yang Diukur Dengan Return on Assets (Studi Kasus Pada Perusahaan Perbankan Yang Terdaftar Di Bei Tahun 2009-2013). Universitas Pandanaran Semarang Jurusan Akuntasi Program S1.

Setiawan, U. N. A., \& Astiwi, I. (2016). Pengaruh Dana Pihak Ketiga (DPK), Capital Adequacy Ratio (CAR), dan Non Performing Financing (NPF) terhadap Profitabilitas Bank Syariah dengan Pembiayaan sebagai Variabel Intervening. Diponegoro Journal of Management, 5(4), 1-11.

Simatupang, A., \& Franzlay, D. (2016). Capital Adequacy Ratio(CAR), Non Performing Financing (NPF), Efisiensi Operasional (BOPO) dan Financing to Deposit Ratio (FDR) Terhadap Profitabilitas Bank Umum Syariah di Indonesia. Administrasi Kantor, 4(2), 466-485.

Sintiya, S. (2018). Analisis Pengaruh BOPO, FDR Dan CAR Terhadap Profitabilitas Bank Umum Syariah Periode 2012-2016 (Studi Kasus pada Bank Umum Syariah di Indonesia Periode 20122016). Institut Agama Islam Negeri Salatiga, 1-68. http://erepository.perpus.iainsalatiga.ac.id/3552/

Siregar, P. A. (2020). Risiko keuangan dan pengaruhnya terhadap profitabilitas bank syariah di indonesia. Africa's Potential for the Ecological Intensification of Agriculture, V(1), 120-141.

Soliha, Evis., dan Taswan. (2002). Pengaruh Kebijakan Hutang terhadap Nilai Perusahaan serta Faktor yang Memengaruhinya. Jurnal Bisnis dan Ekonomi, STIE Stikubank Semarang.

Sukma, N., Saerang, I. S., \& Dkk. (2019). Pengaruh Dana Pihak Ketiga, Risiko Kredit, Risiko Pasar 
Dan Risiko Operasional Terhadap Profitabilitas Pada Bank Kategori Buku 2 Periode 2014-2017. Jurnal EMBA: Jurnal Riset Ekonomi, Manajemen, Bisnis Dan Akuntansi, 7(3), 2751-2760. https://doi.org/10.35794/emba.v7i3.23739

Syah, T. A. (2018). Pengaruh Inflasi, BI Rate, NPF, dan BOPO terhadap Profitabilitas Bank Umum Syariah di Indonesia. El-Jizya: Jurnal Ekonomi Islam, 6(1), 133-153. https://doi.org/10.24090/ej.v6i1.2051

Syakhrun, M., Anwar, A., \& Amin, A. (2019). Pengaruh Car, Bopo, Npf Dan Fdr Terhadap Profitabilitas Pada Bank Umum Syariah Di Indonesia. Bongaya Journal for Research in Management (BJRM), 2(1), 1-10. https://doi.org/10.37888/bjrm.v2i1.102

Ubaidillah, U. (2016). Analisis Faktor-Faktor Yang Mempengaruhi Profitabilitas Bank Syariah Di Indonesia. El-Jizya: Jurnal Ekonomi Islam, 4(1), 1510188. https://doi.org/10.24090/ej.v4i1.2016.pp1510188

Utami, M. S. M., \& Muslikhati. (2019a). Pengaruh Dana Pihak Ketiga ( DPK ), Capital Adequacy Ratio ( CAR ), Non Performing Financing ( NPF ) terhadap Likuiditas Bank Umum Syariah. FALAH Jurnal Ekonomi Syariah, 4, 33-43.

Utami, M. S. M., \& Muslikhati. (2019b). Pengaruh Dana Pihak Ketiga (DPK), Capital Adequacy Ratio (CAR), Non Performing Financing (NPF) terhadap Likuiditas Bank Umum Syariah (BUS) Periode 2015-2017. Falah: Jurnal Ekonomi Syariah, 4(1), 33. https://doi.org/10.22219/jes.v4i1.8495

Wahyuda, K. D. P., H, N. T., \& Dkk. (2017). Pengaruh Pertumbuhan Dana Pihak Ketiga, Pertumbuhan Kredit Dan Bopo Terhadap Profitabilitas Bpr Di Bali Periode 2013-2015. JIMAT (Jurnal Ilmiah Mahasiswa Akuntansi S1), 8(2).

Yundi, N. F., \& Sudarsono, H. (2018). Pengaruh Kinerja Keuangan Terhadap Return on Asset (ROA) Bank Syariah di Indonesia. Al-Amwal: Jurnal Ekonomi Dan Perbankan Syari'ah, 10(1), 18. https://doi.org/10.24235/amwal.v10i1.2759

Yusuf, M. (2017). Dampak Indikator Rasio Keuangan terhadap Profitabilitas Bank Umum Syariah di Indonesia. Jurnal Keuangan Dan Perbankan : ISSN 1829-9865, 13(2), 141-151.

Yusuf, W. M., \& Wahyuni, S. (2017). Pengaruh CAR,NPF,BOPO,FDR,Terhadap ROA Yang Dimediasi Oleh NOM. Journal Bisnis Dan Manajemen, 17, 41-62.

Yusup, S., \& Norita. (2009). Analisis Pengaruh Pertumbuhan Dana Pihak Ketiga, Capital Adequacy Ratio, Net Interest Margin, dan Non Performing Loan Terhadap Return On Assets Pada Bank Yang Terdaftar Di Bursa Efek Indonesia Tahun 2007-2012. Jurnal Telkom University, 20072010 . 